\title{
Analisis Perbandingan Metode Certainty Factor dan Teorema Bayes untuk Mendiagnosa Penyakit Autis Pada Anak
}

\author{
Ramadhanu Ginting ${ }^{1}$, M Zarlis ${ }^{2}$, Rika Rosnelly ${ }^{1}$ \\ ${ }^{1}$ Fakultas Teknik dan Ilmu komputer, Prodi Magister Ilmu Komputer, Universitas Potensi Utama, Medan, Indonesia \\ ${ }^{2}$ Universitas Sumatera Utara, Medan, Indonesia \\ Email: 1," ramadanu.aragi @gmail.com, ${ }^{2}$ m.zarlis@ yahoo.com, ${ }^{3}$ rikarosnelly@gmail.com \\ Email Penulis Korespondensi: ${ }^{1}$ ramadanu.aragi@gmail.com
}

\begin{abstract}
Abstrak-Penelitian ini membahas tentang perancangan sebuah system yang khusus menangani masalah penyakit autis pada anak. Autisme adalah salah satu perilaku yang terjadi kepada seseorang khususnya seorang anak yang menyebabkan sulit berinteraksi sosial. Sistem pakar adalah sebuah system yang merepresentasikan kemampuan seorang pakar ke dalam sebuah mesinDimana pada penelitian ini membahas bagaimana menganalisis 2 metode pada system pakar yaitu Certainty Factor dan Teorema bayes untuk diagnosa penyakit autis pada anak yang bertujuan untuk menentukan metode mana yang paling tepat dan baik untuk digunakan atau diimplementasikan kedalam sebuah aplikasi. yang akan berguna nantinya dalam menentukan kategori anak autisme.Berdasarkan penelitian yang dilakukan penulis didapatkan gambaran sederhana analisis perbandingan metode Certainty Factor dan Teorema Bayes dimana metode Certainty Factor memiliki akurasi perhitungan di atas $90 \%$.
\end{abstract}

Kata Kunci: Autisme; Metode Certainty Factor; Metode Teorema Bayes

\begin{abstract}
This study discusses the design of a system that specifically addresses the problem of autism in children. Autism is a behavior that occurs to a person, especially a child, which makes social interaction difficult. The expert system is a system that represents the ability of an expert into a machine, where in this study, it discusses how to analyze 2 methods in an expert system, namely the Certainty Factor and the Bayes Theorem for diagnosing autism in children which aims to determine which method is the most appropriate and good to use. or implemented into an application. which will be useful later in determining the category of children with autism. Based on the research conducted by the author, a simple description of the comparative analysis of the Certainty Factor and Bayes Theorem methods is obtained where the Certainty Factor method has a calculation accuracy above $90 \%$.
\end{abstract}

Keywords: Autism; Certainty Factor Method; Bayes Theorem Method

\section{PENDAHULUAN}

Salah satu faktor yang menyebabkan semakin meningkatnya jumlah penderita autisme adalah kurangnya pengetahuan dari orang tua dan kurangnya jumlah tenaga ahli yang bisa dijadikan rujukan dan membantu mendiagnosis gejala autisme. Untuk mengatasi kekurangan tenaga ahli dapat dilakukan dengan membuat sistem pakar. Sistem pakar dapat menggantikan tenaga ahli melakukan diagnosis sederhana gejala awal autisme pada anak Penelitian yang dilakukan oleh [1] ."Diagnosa Gangguan Autisme Pada Anak Berbasis Perangkat Bergerak Android" untuk mendeteksi autisme secara dini sehingga khususnya para masyarakat awam dan para orang tua akan adanya gangguan autism pada anak , sehingga informasi tersebut dapat ditindak lanjuti lebih dini. Dengan Deteksi dini gangguan autism pada anak, maka dapat dilakukan penanganan yang tepat dan intensif, sehingga anak dapat berkembang dan tumbuh dengan baik. Tindak lanjut tersebut sebagai upaya untuk pengetahuan masyarakat awam/ orang tua agar lebih lebih tahu, lebih cermat, perhatian dan waspada terhadap tumbuh kembang anak. [2][3].Autism Spectrum Disorder (ASD) atau yang lebih sering kita kenal sebagai autisme, adalah sebuah kelainan pada sistem saraf yang dapat mempengaruhi perkembangan anak. Seringkali orangtua terlambat menyadari bahwa anaknya menderita autis. Hal ini biasa disebabkan karena sedikitnya pengetahuan dan informasi tentang autism [4][5]

Dampak dari autisme berbeda-beda pada setiap tahap perkembangan, dampak autism sebelum masa sekolah yaitu tantrum (ledakan emosi), telat berbicara, kurangnya kontak mata dan senyum sosial, lebih suka menyendiri dan tidak mampu memahami aturan. Setelah memasuki usia sekolah perilaku menarik diri akan berkurang, namun tetap tidak sulit untuk bersosialisasi dengan anak sebayanya dan tidak dapat berempati, terjadi hambatan perkembangan bahasa, dan performa yang tidak seimbang dalam tugas-tugas kognitif[6][7].Salah satu karakteristik anak autis adalah memiliki hambatan dalam rentang perhatian, yang berdampak pada proses pembelajaran. Anak autis memerlukan metode belajar yang sesuai dengan karakteristiknya, agar dapat membantu proses belajarnya [8][9]

Sistem pakar adalah pengembangan kecerdasan buatan dalam bentuk aplikasi praktis[10] .Dalam penelitian lain, dijelaskan bahwa Sistem Pakar adalah salah satu metode yang terdapat dalam kecerdasan buatan yang digunakan untuk mendiagnosis kesalahan sistem dan sebagai pemecahan masalah[11]. Pendapat lain yang menunjukkan bahwa Sistem Pakar adalah hasil dari pengetahuan dan prosedur pencarian [12]. Sistem pakar secara umum adalah sistem yang berusaha yang mengadopsi pengetahuan manusia ke komputer, agar computer dapat menyelesaikan masalah seperti yang biasa dilakukan oleh para ahli. Sistem pakar dikatakan sistem mengadopsikan cara kerja atau pengetahuan manusia ke komputer yang dirancang untuk memodelkan kemampuan masalah seperti seorang pakar [13]. 
Berdasarkan penelitian yang dilakukan Marlika "Sistem Pakar Diagnosa Autisme Pada Anak Berbasis Android" dimana penelitian tersebut menggunakan metode Certainty Factor didapatkan hasil yang memuaskan dimana dibangun sebuah aplikasi berbasis android untuk mendiagnosa apakah seorang anak menderita autisme atau tidak dan hasil yang didapatkan sesuai dengan hasil seorang pakar dan sudah diuji nilai kebenarannya [14]. Penelitian yang sama juga dilakukan oleh Suleman "Perancangan Sistem Pakar Diagnosa Penyakit Autisme Pada Anak Berbasis Android" dimana peneliti menggunakan metode Naïve Bayes sebagai metode dalam memecahkan masalah dari kasus yang penulis angkat dimana didapatkan hasil yang memuaskan yang mampu membuat sebuah system berbasis android untuk mendiagnosa penyakit autism pada anak serta membantu orang tua dan guru untuk segera mungkin menangani anak yang didiagnosa menderita autism [17]. Berkaitan dengan hal tersebut maka penulis mengambil judul penelitian untuk membandingkan 2 metode dari sistem pakar yaitu metode Certainty Factor dan Teorema bayes untuk menganalisa dan menentukan metode mana yang lebih baik digunakan dalam mendiagnosis anak penderita autisme.

\section{METODOLOGI PENELITIAN}

\subsection{Kerangka Kerja Penelitian}

Kerangka kerja riset terbuat secara sistematis yang menuju pada tahapan proses yang hendak ditempuh pada riset ini bisa dilihat pada gambar 1.

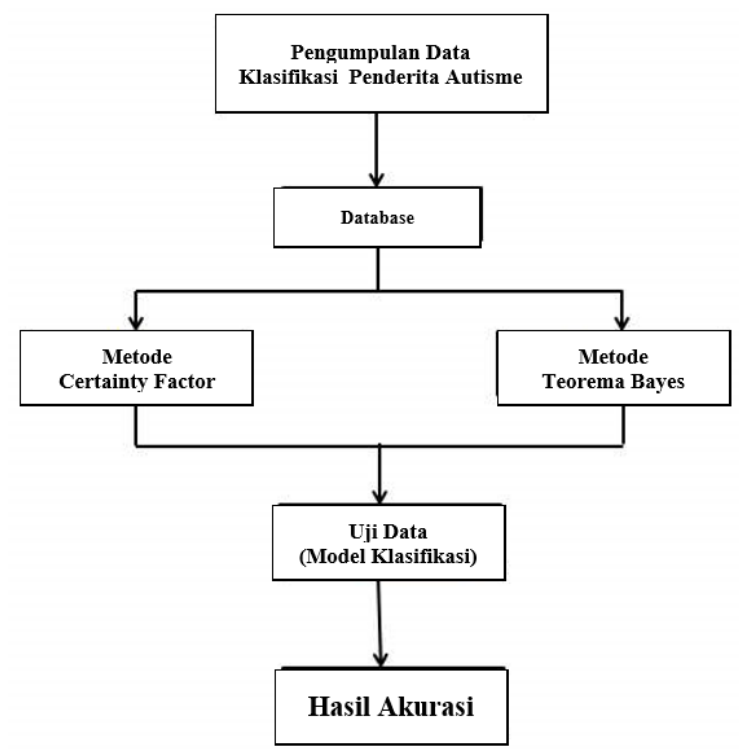

Gambar 1. Kerangka Penelitian

Berikut penjelasan dari gambar 1, diatas:

\section{Pengumpulan Data}

Pada tahapan ini peneliti mengumpulkan data-data teori yang terkait dengan penelitian.Dimana data yang di dapatkan bersumber dari literature Jurnal , Buku, Website serta Riset yang dilakukan ke Sekolah Luar Biasa (SLB) Al - Azhar Medan.

\section{Database}

Pada tahap ini dilakukan pengumpulan dan pengolahan data sehingga menjadi database yang menjadi informasi yang akan diolah.Database yang dimaksud penulis berupa data gejala anak penderita Autisme, Jenis Autisme dimana terbagi menjadi 3 Jenis Autisme yaitu Interaksi Sosial, Komunikasi dan Pola Perilaku sesuai dengan buku rujukan dengan Judul DSM - IV "Diagnostic and Statistical Manual Of Mental Disorder “,serta nilai densitas dari tiap gejala [18].

\section{Metode}

Pada tahapan ini peneliti menggunakan perbandingan metode yaitu Certainty factor dan Teorema Bayes. Ditahapan ini dilakukan proses perhitungan secara manual dari contoh kasus yang penulis sajikan.

\section{Uji Data}

Pada tahapan ini peneliti melakukan tahapan proses penelitian dan melakukan uji coba perbandingan metode. Setelah itu peneliti melakukan penentuan sesuai pengumpulan data untuk menentukan metode mana yang terbaik untuk digunakan.

\section{Hasil Akurasi}

Pengujian secara praktek menggunakan aplikasi perhitungan menggunakan Microsoft Office Excell dimana pengujian dilakukan dengan menguji sample kemungkinan gejala dengan jenis autis yang mungkin diderita seorang anak. 


\subsection{Sistem Pakar}

Sistem Pakar termasuk sekelompok kecerdasan buatan yang memiliki pengetahuan khusus di mana pengetahuan ini bisa terus berkembang dan di update sesuai dengan perkembangan jaman sehingga dapat memecahkan masalah yang ada secara cepat yang selama ini tidak begitu cepat dan effisien serta membutuhkan biaya dalam mencari penyelesaian untuk pemecahan masalahnya .

\subsection{Metode Certainty Factor}

Metode Certainty Factor (CF) ini dipilih ketika dalam menghadapi suatu masalah, sering ditemukan jawaban yang tidak memiliki kepastian penuh. Untuk mengakomodasi hal ini maka digunakan Certainty Factor (CF) guna menggambarkan tingkat keyakinan pakar terhadap masalah yang sedang dihadapi[15].

Berikut perhitungan Certainty Factor untuk kombinasi dua buah rule dengan evidence berbeda (E1 dan E2), tetapi hipotesisnya sama:

$$
C F\left(C F_{1}, C F_{2}\right)=\begin{gathered}
C F_{1}+C F_{2}\left(1-C F_{1}\right) \quad \text { Jika } C_{1} \text { atau } C F_{2}>0 \\
\frac{C F_{1}+C F_{2}}{1-\min \left[C F_{1}, C F_{2}\right]} \quad \text { Jika } C F_{1} \text { atau } C F_{2}<0 \quad(1) \\
C F_{1}+C_{2}\left(1-C F_{1}\right) \quad \text { Jika } C F_{1} \text { atau } C F_{2}>0
\end{gathered}
$$

\subsection{Metode Teorema Bayes}

Teorema Bayes adalah aturan yang menggunakan probabilitas untuk menghasilkan keputusan dan informasi yang tepat .Berikut persamaan Teorema Bayes :

$$
P\left(M_{i} \mid S\right)=\frac{P\left(S \cap M_{i}\right)}{P(S)}
$$

\subsection{Autisme}

Autisme adalah sebuah kelainan yang mempengaruhi perkembangan anak yang termasuk dalam Pervasive Development Disorder (PDD). Autisme sering diasosiasikan dengan cacat mental, kesulitan melakukan gerakan kompleks, kesulitan dalam mengarahkan perhatian, dan lambatnya perkembangan kepribadian pada anak[16].

\section{HASIL DAN PEMBAHASAN}

\subsection{Data Gejala, Nilai Densitas Serta Jenis Autisme}

Dilakukan pengumpulan data, yaitu berupa data gelaja, nilai densitas setiap gejala serta klasifikasi jenis autism yang mungkin dialami seorang anak.Dimana data di peroleh dari hasil Literasi Jurnal, Buku, Website serta Riset

\begin{tabular}{|c|c|c|c|c|}
\hline No & Gejala & Kode Gejala & $\begin{array}{c}\text { Nilai } \\
\text { Densitas }\end{array}$ & $\begin{array}{c}\text { Jenis } \\
\text { Autisme }\end{array}$ \\
\hline 1 & $\begin{array}{l}\text { Tertawa-tawa sendiri, menangis atau marah tanpa } \\
\text { sebab }\end{array}$ & G1 & 0.8 & \multirow{7}{*}{$\begin{array}{c}\text { Interaksi } \\
\text { Sosial }\end{array}$} \\
\hline 2 & Sering mengamuk tak terkendali & $\mathrm{G} 2$ & 0.6 & \\
\hline 3 & Tidak dapat berbagi dengan perasaan orang lain & G3 & 0.5 & \\
\hline 4 & Menolak atau menghindar untuk bertatap muka & G4 & 0.7 & \\
\hline 5 & Tidak menoleh bila dipanggil & G5 & 0.4 & \\
\hline 6 & Menolak dipeluk & G6 & 0.3 & \\
\hline 7 & Tidak berbagi kesenangan dengan orang lain & G7 & 0.3 & \\
\hline 8 & Saat bermain, bila didekati malah menjauh & G8 & 0.3 & \multirow{10}{*}{ Komunikasi } \\
\hline 9 & Bermain sangat monoton dan aneh & G9 & 0.5 & \\
\hline 10 & Tidak dapat berimajinasi dalam bermain & G10 & 0.3 & \\
\hline 11 & Perkembangan berbahasa mengalami keterlambatan & G11 & 0.6 & \\
\hline 12 & Kata-kata yang tidak dapat dimengerti orang lain & G12 & 0.8 & \\
\hline 13 & Menirukan kata, kalimat atau lagu tanpa tahu artinya & G13 & 0.7 & \\
\hline 14 & Bicaranya monoton seperti robot & G14 & 0.5 & \\
\hline 15 & Mimik datar & G15 & 0.8 & \\
\hline 16 & Berkomunikasi dengan menggunakan bahasa tubuh & G16 & 0.4 & \\
\hline 17 & $\begin{array}{l}\text { Sering memperhatikan jari-jarinya sendiri atau kipas } \\
\text { angin yang berputar }\end{array}$ & G17 & 0.8 & \\
\hline 18 & Jika senang satu mainan tidak mau mainan yang & G18 & 0.5 & Perilaku \\
\hline
\end{tabular}
yang di lakukan penulis Ke Sekolah Luar Biasa (SLB) Al - Azhar.

Tabel 1. Daftar Gejala, Nilai Densitas dan Jenis Autisme 


\begin{tabular}{|c|c|c|c|c|}
\hline No & Gejala & Kode Gejala & $\begin{array}{c}\text { Nilai } \\
\text { Densitas }\end{array}$ & $\begin{array}{c}\text { Jenis } \\
\text { Autisme }\end{array}$ \\
\hline & lainnya & & & \\
\hline 19 & Bila bepergian harus melalui rute yang sama & G19 & 0.6 & \\
\hline 20 & Ada kelekatan dengan benda tertentu & G20 & 0.3 & \\
\hline 21 & Sering dianggap anak yang senang kerapian & G21 & 0.3 & \\
\hline 22 & Mengulang suatu gerakan tertentu & G22 & 0.7 & \\
\hline 23 & Dapat menjadi sangat hiperaktif atau hipoaktif & G23 & 0.8 & \\
\hline 24 & Mengalami gangguan makan & G24 & 0.3 & \\
\hline
\end{tabular}

Berdasarkan data kepakaran diagnose autism pada anak pada tabel 1, dapat dibentuk basis aturan (rule), adapun aturan (rule) yang dibentuk adalah sebagai berikut :

Rule 1 : IF Tertawa-tawa sendiri, menangis atau marah tanpa sebab =Yes AND Sering mengamuk tak terkendali $=$ Yes $A N D$ Tidak dapat berbagi dengan perasaan orang lain $=$ Yes $A N D$ Tidak menoleh bila dipanggil $=$ Yes $A N D$ Menolak dipeluk =Yes $A N D$ Tidak berbagi kesenangan dengan orang lain=Yes $A N D$ Saat bermain, bila didekati malah menjauh $=$ Yes THEN Jenis Autisme= Interaksi Sosial.

Rule 2 : IF Bermain sangat monoton dan aneh =Yes $A N D$ Tidak dapat berimajinasi dalam bermain $=$ Yes $A N D$ Perkembangan berbahasa mengalami keterlambatan $=$ Yes $A N D$ Kata-kata yang tidak dapat dimengerti orang lain $=$ Yes $A N D$ Menirukan kata, kalimat atau lagu tanpa tahu artinya =Yes $A N D$ Bicaranya monoton seperti robot $=$ Yes $A N D$ Mimik datar $=$ Yes $A N D$ Berkomunikasi dengan menggunakan bahasa tubuh $=$ Yes THEN Jenis Autisme $=$ Komunikasi

Rule 3 : IF Sering memperhatikan jari-jarinya sendiri atau kipas angin yang berputar =Yes AND Jika senang satu mainan tidak mau mainan yang lainnya =Yes $A N D$ Bila bepergian harus melalui rute yang sama $=$ Yes $A N D$ Ada kelekatan dengan benda tertentu =Yes $A N D$ Sering dianggap anak yang senang kerapian $=$ Yes $A N D$ Mengulang suatu gerakan tertentu $=$ Yes $A N D$ Dapat menjadi sangat hiperaktif atau hipoaktif =Yes $A N D$ Mengalami gangguan makan =Yes THEN Jenis Autisme = Pola Perilaku.

\subsection{Analisis Metode Certainty Factor}

Pada Tahap ini penulis memberikan gambaran contoh kasus seorang anak penderita autisme di mana anak tersebut memiliki 4 Gejala autisme dan akan di cari diagnosa jenis autisme serta akan dihitung berapa nilai kemungkinan dari diagnosa jenis autisme tersebut.

Diketahui Seorang anak memiliki Gejala Autisme yaitu Bila bepergian harus melalui rute yang sama (G19), Mengulang suatu gerakan tertentu (G22), Dapat menjadi dangat hiperaktif atau hipoaktif (G23) dan Perkembangan berbahasa mengalami keterlambatan (G11).Berdasarkan data di atas, Jenis Autisme apakah yang di derita anak tersebut dan berapa nilai Probalitasnya ?

\section{Menelusuri runut maju terhadap rule-rule yang ada}

Rule 1 : IF Bila bepergian harus melalui rute yang sama =Yes $A N D$ Mengulang suatu gerakan tertentu =Yes $A N D$ Dapat menjadi dangat hiperaktif atau hipoaktif =Yes THEN Jenis Autisme = Pola Perilaku.

Rule 2 : IF Perkembangan berbahasa mengalami keterlambatan =Yes THEN Jenis Autisme = Komunikasi.

Berdasarkan hasil dari proses penelusuran dengan menggunakan teknik inferensi Forward Chaining, diketahui bahwa anak tersebut memiliki karateristik Jenis Autisme : Pola Perilaku dan Komunikasi.

2. Melakukan proses perhitungan dengan metode Certainty Factor sesuai dengan persamaan rumus (1) dan identifikasi nilai kepastian gejala didapat dari tabel kepastian 1 :

a. Jenis Autisme Pola Perilaku:

$$
\begin{array}{ll}
(\mathrm{G} 19, \mathrm{G} 22) & =0.6+0.7(1-0.6)=0.88(\mathrm{CF} \text { kom }) \\
(\mathrm{Cf} \text { kom dan G23 }) & =0.88+0.8(1-0.88)=0.976(\text { Hasil CF })
\end{array}
$$

Maka hasil dari perhitungan dengan metode Certainty Factor terhadap 3 gejala untuk Jenis Autisme Pola Perilaku adalah 0.976 atau $97 \%$.

b. Jenis Autisme Komunikasi :

$$
\text { (G11) } \quad=0.6+0(1-0.6)=0.6(\text { Hasil CF })
$$

Maka hasil dari perhitungan dengan metode Certainty Factor terhadap 1 gejala untuk Jenis Autisme Komunikasi adalah 0.6 atau $60 \%$.

\section{Kesimpulan Perhitungan}

Nilai Max (Pola Perilaku dan Komunikasi $)=(0.97 ; 0.6)=0.97$

Maka hasil diagnosa yang didapat dari kasus di atas, bahwa pasien anak kemungkinan besar memiliki Autisme dengan Jenis Autisme Pola Perilaku dengan tingkat probabilitas terhadap Jenis Autisme tesebut adalah 0.97 atau $97 \%$. 
Tabel 2. Hasil Diagnosa kasus 4 Gejala

\begin{tabular}{cclcc}
\hline No & Kode & \multicolumn{1}{c}{ Gejala } & $\begin{array}{c}\text { Jenis } \\
\text { Autisme }\end{array}$ & $\begin{array}{c}\text { Nilai } \\
\text { Kemungkinan }\end{array}$ \\
\hline \multirow{3}{*}{1} & \multirow{2}{*}{ K001 } & $\begin{array}{l}\text { 1.Bila bepergian harus melalui rute yang sama (G19) } \\
\text { 2. Mengulang suatu gerakan tertentu (G22) } \\
\text { 3.Dapat menjadi dangat hiperaktif atau hipoaktif (G23) } \\
\text { 4.Perkembangan berbahasa mengalami keterlambatan (G11) }\end{array}$ & Pola & Perilaku \\
& & & \\
\hline
\end{tabular}

\subsection{Analisis Metode Teorema Bayes}

Pada Tahap ini penulis memberikan gambaran contoh kasus seorang anak penderita autisme di mana anak tersebut memiliki 4 Gejala autisme dan akan di cari diagnosa jenis autisme serta akan dihitung berapa nilai kemungkinan dari diagnosa jenis autism tersebut.Contoh kasus di samakan dengan contoh kasus metode Certainty Factor.

Diketahui Seorang anak memiliki Gejala Autisme yaitu Bila bepergian harus melalui rute yang sama (G19), Mengulang suatu gerakan tertentu (G22), Dapat menjadi dangat hiperaktif atau hipoaktif (G23) dan Perkembangan berbahasa mengalami keterlambatan (G11).Berdasarkan data di atas, Jenis Autisme apakah yang di derita anak tersebut dan berapa nilai Probalitasnya ?

\section{Menelusuri runut maju terhadap rule-rule yang ada}

Rule 1 : IF Bila bepergian harus melalui rute yang sama =Yes AND Mengulang suatu gerakan tertentu =Yes $A N D$ Dapat menjadi dangat hiperaktif atau hipoaktif =Yes THEN Jenis Autisme = Pola Perilaku.

Rule 2 : IF Perkembangan berbahasa mengalami keterlambatan $=$ Yes $T H E N$ Jenis Autisme $=$ Komunikasi.

Berdasarkan hasil dari proses penelusuran dengan menggunakan teknik inferensi Forward Chaining, diketahui bahwa anak tersebut memiliki karateristik Jenis Autisme : Pola Perilaku dan Komunikasi.

\section{Melakukan proses perhitungan dengan Metode Teorema Bayes sesuai dengan persamaan rumus (2) dan} identifikasi nilai kepastian gejala didapat dari tabel kepastian 1 :

a. Jenis Autisme Pola Perilaku:

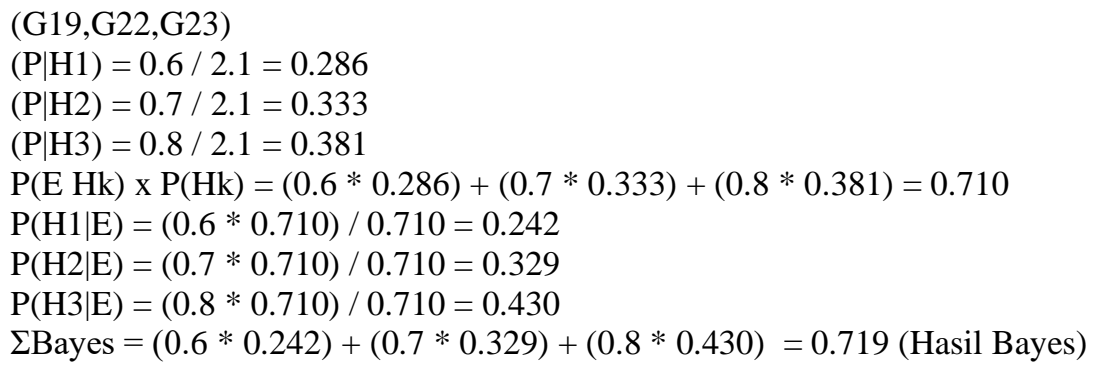

Maka hasil dari perhitungan dengan metode Teorema Bayes untuk Jenis Autisme Pola Perilaku adalah 0.71 atau $71 \%$.

b. Jenis Autisme Komunikasi:

$$
\begin{aligned}
& (\mathrm{P} \mid \mathrm{H} 1)=0.6 / 0.6=1 \\
& \mathrm{P}(\mathrm{H} 1 \mid \mathrm{E})=(0.6 * 1) / 1=0.6 \\
& \Sigma \text { Bayes }=(0.6 * 0.6)=0.36 \text { (Hasil Bayes) }
\end{aligned}
$$

Maka hasil dari perhitungan dengan metode Teorema Bayes untuk Jenis Autisme Komunikasi adalah 0.36 atau $36 \%$.

\section{Kesimpulan Perhitungan}

Nilai Max $($ Pola Perilaku dan Komunikasi $)=(0.71 ; 0.36)=0.71$

Maka hasil diagnosa yang didapat dari kasus di atas, bahwa pasien anak kemungkinan besar memiliki Autisme dengan Jenis Autisme Pola Perilaku dengan tingkat probabilitas terhadap Jenis Autisme tesebut adalah 0.71 atau $71 \%$.

Tabel 3. Hasil Diagnosa kasus 4 Gejala

\begin{tabular}{ccccc}
\hline No & Kode & \multicolumn{1}{c}{ Gejala } & $\begin{array}{c}\text { Jenis } \\
\text { Autisme }\end{array}$ & $\begin{array}{c}\text { Nilai } \\
\text { Kemungkinan }\end{array}$ \\
\hline \multirow{3}{*}{1} & \multirow{2}{*}{ K001 } & $\begin{array}{l}\text { 1.Bila bepergian harus melalui rute yang sama (G19) } \\
\text { 2. Mengulang suatu gerakan tertentu (G22) } \\
\text { 3.Dapat menjadi dangat hiperaktif atau hipoaktif (G23) } \\
\text { 4.Perkembangan berbahasa mengalami keterlambatan (G11) }\end{array}$ & Pola & $71 \%$ \\
\hline
\end{tabular}




\subsection{Hasil Perbandingan Metode}

Setelah melakukan perhitungan dengan menggunakan metode Certainty Factor dan Teorema Bayes, untuk contoh kasus baru maka di dapatkan kesimpulan perbandingan metode seperti yang terdapat pada table 3 , Berikut ini:

Tabel 4. Hasil Perbandingan Metode Certainty Factor dan Teorema Bayes

\begin{tabular}{|c|c|c|c|c|c|c|c|}
\hline \multirow[b]{3}{*}{ No } & \multirow[b]{3}{*}{ Nama } & \multirow[b]{3}{*}{ Gejala } & \multirow[b]{3}{*}{$\begin{array}{l}\text { Diagnosa } \\
\text { Pakar }\end{array}$} & \multicolumn{4}{|c|}{ Hasil Diagnosa } \\
\hline & & & & \multicolumn{2}{|c|}{ Certainty Factor } & \multicolumn{2}{|c|}{ Teorema Bayes } \\
\hline & & & & $\begin{array}{c}\text { Jenis } \\
\text { Autisme }\end{array}$ & $\begin{array}{c}\text { Nilai } \\
\text { Densitas } \\
\%\end{array}$ & $\begin{array}{c}\text { Jenis } \\
\text { Autisme }\end{array}$ & $\begin{array}{c}\text { Nilai } \\
\text { Densitas } \\
\%\end{array}$ \\
\hline 1 & Achmad & $\begin{array}{l}\text { G17,G18,G22, } \\
\text { G23 }\end{array}$ & Pola Perilaku & Pola Perilaku & 99.4 & $\begin{array}{l}\text { Pola } \\
\text { Perilaku }\end{array}$ & 73.9 \\
\hline 2 & $\begin{array}{l}\text { Annisa } \\
\text { Hayfa }\end{array}$ & $\mathrm{G} 17, \mathrm{G} 22, \mathrm{G} 23$ & Pola Perilaku & Pola Perilaku & 98.8 & $\begin{array}{c}\text { Pola } \\
\text { Perilaku }\end{array}$ & 77.2 \\
\hline 3 & Dana Dwi & G11,G14,G15 & Komunikasi & Komunikasi & 96 & Komunikasi & 68.2 \\
\hline 4 & M. Rasya & $\begin{array}{l}\text { G9,G12,G14, } \\
\text { G15 }\end{array}$ & Komunikasi & Komunikasi & 99 & Komunikasi & 71.6 \\
\hline 5 & Zaki & $\mathrm{G} 9, \mathrm{G} 11, \mathrm{G} 14$ & Komunikasi & Komunikasi & 90 & Komunikasi & 54.2 \\
\hline 6 & Salsabila & G11,G12 & Komunikasi & Komunikasi & 92 & Komunikasi & 72.8 \\
\hline 7 & Ulfaira & G1,G2,G5,G8 & $\begin{array}{l}\text { Interaksi } \\
\text { Sosial }\end{array}$ & $\begin{array}{l}\text { Interaksi } \\
\text { Sosial }\end{array}$ & 96.6 & $\begin{array}{l}\text { Interaksi } \\
\text { Sosial }\end{array}$ & 65.5 \\
\hline 8 & Raihan & $\mathrm{G} 19, \mathrm{G} 21, \mathrm{G} 22$ & Pola Perilaku & Pola Perilaku & 91.6 & $\begin{array}{l}\text { Pola } \\
\text { Perilaku }\end{array}$ & 62.3 \\
\hline 9 & Abbrar & $\mathrm{G} 1, \mathrm{G} 2, \mathrm{G} 3$ & $\begin{array}{c}\text { Interaksi } \\
\text { Sosial }\end{array}$ & $\begin{array}{l}\text { Interaksi } \\
\text { Sosial }\end{array}$ & 96 & $\begin{array}{l}\text { Interaksi } \\
\text { Sosial }\end{array}$ & 68. \\
\hline 10 & Fatimah & G3,G4,G5,G7 & $\begin{array}{l}\text { Interaksi } \\
\text { Sosial }\end{array}$ & $\begin{array}{l}\text { Interaksi } \\
\text { Sosial }\end{array}$ & 93.7 & $\begin{array}{c}\text { Interaksi } \\
\text { Sosial }\end{array}$ & 56.5 \\
\hline
\end{tabular}

Maka langkah berikutnya yang harus di lakukan adalah dengan menentukan metode mana yang paling tepat dan baik untuk melakukan pendiagnosaan penyakit Autisme Pada Anak.Berdasarkan data dari hasil perhitungan metode Certainty Factor dan Teorema Bayes, maka diperoleh kesimpulan sebagai berikut :

1. Pada perhitungan untuk contoh kasus 4 gejala dengan metode Certainty Factor Jenis Autisme yang terpilih adalah Pola Perilaku dengan nilai probabilitas 0.97 dan metode Teorema Bayes didapatkan hasil jenis autisme yang sama yaitu Pola Prilaku dengan nilai Propabilitas 0,71. Dari hasil perhitungan tersebut maka metode Certainty Factor adalah metode yang memiliki nilai probabilitas tertinggi dibandingkan metode Teorema Bayes.

2. Berdasarkan Tabel.3.Hasil Perbandingan Metode Certainty Factor dan Teorema Bayes didapatkan hasil dimana dari 10 anak penderita autisme yang didiagnosa metode Certainty Factor memiliki keunggulan keakuratan dalam menentukan jenis autisme pada anak dibuktikan dengan nilai densitas metode Certainty Factor lebih tinggi di banding nilai densitas metode Teorema Bayes..

3. Dalam kasus mengidentifikasi jenis Autisme pada Anak, metode Certainty Factor dan Teorema Bayes, memiliki kesamaan pola ini terlihat dari hasil yang diperoleh yaitu jika gejala semakin banyak maka nilai probabilitas jenis penyakit akan semakin tinggi.Namun untuk metode Teorema Bayes memiliki nilai probabilitas yang diperoleh lebih kecil dibandingkan dengan nilai probabilitas metode Certainty Factor.

4. Berdasarkan penjelasan sebelumnya, maka didapatkan hasil untuk mendiganosa penyakit Autisme Pada Anak, metode yang paling tepat dan baik adalah metode Certainty Factor. Hal ini sesuai dengan ilmu kepakaran bahwa satu penyakit tidak dapat ditetapkan hanya dengan satu gejala atau dengan kata lain nilai probabilitasnya rendah dan semakin banyak gejala-gejala yang diderita maka semakin mungkin terdiagnosa jenis penyakit tersebut dengan nilai probabilitasnya yang tinggi.

\section{KESIMPULAN}

Berdasarkan hasil pembahasan untuk menganalisis perbandingan metode Certainty Factor dan Teorema Bayes maka dapat diperoleh beberapa kesimpulan, adapun kesimpulan tersebut sebagai berikut : Berdasarkan hasil perhitungan yang telah dilakukan maka dapat diketahui bahwa metode Certainty Factor adalah metode yang memiliki nilai probabilitas tertinggi dibandingkan metode Teorema Bayes. Dengan hasil perhitungan ini maka nantinya implementasi sistem pakar untuk mendiagnosa penyakit Autisme pada Anak adalah dengan menggunakan metode Certainty Factor. 
JURNAL MEDIA INFORMATIKA BUDIDARMA

Volume 5, Nomor 2, April 2021, Page 583-589

ISSN 2614-5278 (media cetak), ISSN 2548-8368 (media online)

Available Online at https://ejurnal.stmik-budidarma.ac.id/index.php/mib

DOI 10.30865/mib.v5i2.2930

\section{UCAPAN TERIMAKASIH}

Terima kasih disampaikan kepada pihak-pihak yang telah mendukung terlaksananya penelitian ini.

\section{REFERENCES}

[1] H. F. Qoriani, A. Ambarwati, S. Informasi, F. I. Komputer, and U. N. Surabaya, "Diagnosa gangguan autisme pada anak berbasis perangkat bergerak android," vol. 23, no. 2, pp. 7-13, 2015.

[2] M. Aldrin, Z. Zukhri, and A. B. Cahyono, "Sistem Pakar untuk Mendiagnosis Autisme," Semin. Nas. Inform. Medis, vol. 8, pp. 60-61, 2017.

[3] R. Rachman, "Penerapan Sistem Pakar Untuk Diagnosa Autis Dengan Metode Forward Chaining," J. Inform., vol. 6, no. 2, pp. 218-225, 2019, doi: 10.31311/ji.v6i2.5522.

[4] W. O. I. Amir, "Identifikasi Tingkat Pengetahuan Ibu Tentang Diet Casein Free dan Gluten Free pada Anak Autis," JOM FKp, Vol., vol. 5, no. 2, pp. 677-682, 2018.

[5] S. Siyoto, "Visual Schedule towards the Decline of Behavioral Problems in Feeding Activities and Defecation in Children with Autism," J. NERS, vol. 10, no. 2, p. 250, 2015, doi: 10.20473/jn.v10i22015.250-255.

[6] Asrizal, "Penanganan Anak Autis dalam Interaksi Sosial," J. PKS, vol. 15, no. 1, pp. 1-8, 2016.

[7] R. Dewi, Inayatillah, and R. Yullyana, "Pengalaman Orangtua dalam Mengasuh Anak Autis di Kota Banda Aceh," Psikoislamedia J. Psikol., vol. 3, no. 2, pp. 288-301, 2018.

[8] T. Ballerina, "Meningkatkan Rentang Perhatian Anak Autis dalam Pembelajaran Pengenalan Huruf," Inklusi, vol. 3, no. 2, p. 245, 2017, doi: 10.14421/ijds.030205.

[9] L. S. A. Prasetyoningsih, "Pengembangan Tindak Bahasa Terapi Dalam Intervensi Anak Autis Spektrum Perilaku," Litera, vol. 15, no. 1, pp. 120-127, 2016, doi: 10.21831/ltr.v15i1.9771.

[10] A. Al-Ajlan, "The Comparison between Forward and Backward Chaining," Int. J. Mach. Learn. Comput., vol. 5, no. 2, pp. 106-113, 2015, doi: 10.7763/ijmlc.2015.v5.492.

[11] T. Wang, G. Zhang, J. Zhao, Z. He, J. Wang, and M. J. Perez-Jimenez, "Fault diagnosis of electric power systems based on fuzzy reasoning spiking neural p systems," IEEE Trans. Power Syst., vol. 30, no. 3, pp. 1182-1194, 2015, doi: 10.1109/TPWRS.2014.2347699.

[12] M. S. Hossain, F. Ahmed, Fatema-Tuj-Johora, and K. Andersson, "A Belief Rule Based Expert System to Assess Tuberculosis under Uncertainty,” J. Med. Syst., vol. 41, no. 3, 2017, doi: 10.1007/s10916-017-0685-8.

[13] P. S. Ramadhan and U. F. S. Pane, "Analisis Perbandingan Metode (Certainty Factor, Dempster Shafer dan Teorema Bayes) untuk Mendiagnosa Penyakit Inflamasi Dermatitis Imun pada Anak," J. SAINTIKOM (Jurnal Sains Manaj. Inform. dan Komputer), vol. 17, no. 2, pp. 151-157, 2018.

[14] M. T. Pallangan, V. C. Poekoel, and A. Sambul, "Sistem Pakar Diagnosa Autisme pada Balita Berbasis Android," J. Tek. Inform., vol. 10, no. 1, pp. 1-7, 2017, doi: 10.35793/jti.10.1.2017.15804.

[15] D. Nofriansyah, P. S. Ramadhan, and B. Andika, "Perancangan Aplikasi Sistem Pakar untuk Mendeteksi Jenis Racun dan Spesies Ular pada Pasien yang Terkena Racun Bisa Ular Menggunakan Metode Certainty Factor," J. SAINTIKOM, vol. 14, no. 2, pp. 93-104, 2015.

[16] T. Arifadhi and N. Susanti, "Pengaruh Penatalaksanaan Fisioterapi Pada Anak Kondisi Autisme Dengan Modalitas Play Exercise (Perceptual Motor Program) Dan Hidroterapi (Balance and Coordination) Di YPAC Surakarta," J. PENA, vol. 33, no. 2, pp. 53-62, 2019.

[17] Suleman,"Perancangan Sistem Pakar Diagnosa Penyakit Autisme Pada Anak Berbasis Android", Journal Speed Sentra Penelitian Engineering dan Edukasi - Volume 10 No 1 - 2018

[18] American Psychiatric Assosiation,"Buku DSM - IV -Diagnostic and Statistical Manual Of Mental Disorder". 